Acta Crystallographica Section D

Biological

Crystallography

ISSN 0907-4449

\title{
Structural characterization and comparison of three acyl-carrier-protein synthases from pathogenic bacteria
}

Some bacterial type II fatty-acid synthesis (FAS II) enzymes have been shown to be important candidates for drug discovery. The scientific and medical quest for new FAS II protein targets continues to stimulate research in this field. One of the possible additional candidates is the acyl-carrierprotein synthase (AcpS) enzyme. Its holo form posttranslationally modifies the apo form of an acyl carrier protein (ACP), which assures the constant delivery of thioester intermediates to the discrete enzymes of FAS II. At the Center for Structural Genomics of Infectious Diseases (CSGID), AcpSs from Staphylococcus aureus $\left(\mathrm{AcpS}_{\mathrm{SA}}\right)$, Vibrio cholerae $\left(\mathrm{AcpS}_{\mathrm{VC}}\right)$ and Bacillus anthracis $\left(\mathrm{AcpS}_{\mathrm{BA}}\right)$ have been structurally characterized in their apo, holo and product-bound forms, respectively. The structure of $\mathrm{AcpS}_{\mathrm{BA}}$ is emphasized because of the two $3^{\prime}, 5^{\prime}$-adenosine diphosphate $\left(3^{\prime}, 5^{\prime}\right.$-ADP $)$ product molecules that are found in each of the three coenzyme A $(\mathrm{CoA})$ binding sites of the trimeric protein. One $3^{\prime}, 5^{\prime}$-ADP is bound as the $3^{\prime}, 5^{\prime}$-ADP part of CoA in the known structures of the CoA-AcpS and $3^{\prime}, 5^{\prime}-\mathrm{ADP}-\mathrm{AcpS}$ binary complexes. The position of the second $3^{\prime}, 5^{\prime}$-ADP has never been described before. It is in close proximity to the first $3^{\prime}, 5^{\prime}$-ADP and the ACP-binding site. The coordination of two ADPs in $\mathrm{AcpS}_{\mathrm{BA}}$ may possibly be exploited for the design of AcpS inhibitors that can block binding of both CoA and ACP.

\section{Introduction}

Pathogenic microorganisms, including Staphylococcus aureus, Bacillus anthracis and Vibrio cholerae, remain a serious threat to human life owing to the infections that they cause and their increasing resistance to current antibiotics. The type II fattyacid synthesis (FAS II) pathway of these bacteria has attracted scientific and medical research and provides multiple targets for drug discovery, since the fatty-acid products of this enzymatic network play a vital role in the life cycle of the pathogens (Maier et al., 2006). FAS II is a dissociated system which is composed of discrete monofunctional proteins that have been extensively studied in Escherichia coli (Magnuson et al., 1993; White et al., 2005). In contrast, the mammalian type I FAS (FAS I) is a single homodimeric polypeptide of $\sim 2500$ residues (Maier et al., 2006, 2008; White et al., 2005; Smith et al., 2003; Wakil et al., 1983; Leibundgut et al., 2008) and the yeast FAS $\mathrm{I}$ is a two-subunit protein that forms a functional megacomplex (Leibundgut et al., 2007, 2008; Jenni et al., 2007). Differences in activity and product distribution that arise from the structural and mechanistic details of the two pathways have been used in antibacterial drug discovery
Received 3 February 2012

Accepted 26 June 2012

PDB References: Staphylococcus aureus AcpS, 3f09; Bacillus anthracis AcpS, 3hyk; Vibrio cholerae AcpS, 3qmn. 
(Zhang et al., 2006). However, there are contradictory data about whether FAS II of the Gram-positive bacteria may be an effective drug target (Wang et al., 2006, 2007; Zhang \& Rock, 2008; Brinster et al., 2009; Campbell \& Cronan, 2001), since the pathogens can utilize exogenous fatty acids in human serum and their uptake can overcome inhibition (Brinster $e t$ al., 2009). Further complications are that FAS I has been found in Mycobacterium tuberculosis (Schweizer \& Hofmann, 2004) and FAS II enzymes are present in eukaryotic mitochondria (Chuman \& Brody, 1989; Schneider, Brors, Burger et al., 1997; Schneider, Brors, Massow et al., 1997; Miinalainen et al., 2003; Brody et al., 1997).

Coenzyme A (CoA) and the holo form of acyl carrier protein (ACP) are key substrates of fatty-acid (Magnuson et al., 1993), polyketide and nonribosomal peptide synthases (Lambalot \& Walsh, 1995). Holo-ACP is also involved in tetrahydrofolate and lysine metabolism (Praphanphoj et al., 2001; Nishida \& Nishiyama, 2000; Donato et al., 2007). In FAS II, functionally active ACP shuttles growing acyl chains between the initiation-module and elongation-cycle enzymes, which together with ACP (Zhang et al., 2004) have been identified as key drug targets (Wang et al., 2006; Zhang et al., 2006). The active form of ACP is produced by a posttranslational modification of a conserved serine residue of apo-ACP by a $4^{\prime}$-phosphopantetheine (P-pant) group transferred from $\mathrm{CoA}$ bound to a holo-(acyl-carrier-protein) synthase (AcpS) (Elovson \& Vagelos, 1968; Flugel et al., 2000). After the holo-ACP has transferred an acyl chain to the next enzyme in FAS II, a protein with ACP phosphodiesterase activity can hydrolyze the P-pant group from the carrier protein, thus completing the ACP-turnover cycle (Vagelos \& Larrabes, 1967; Powell et al., 1969; Jackowski \& Rock, 1984; Fischl \& Kennedy, 1990; Nakanishi et al., 2001), which has been hypothesized to regulate FAS (Elovson \& Vagelos, 1975; Vagelos, 1973). Accumulation of apo-ACP is toxic to Escherichia coli (Keating et al., 1995) and the apo-ACP pool has only been detected under extended depletion of $\mathrm{CoA}$ in the presence of amino acids in the growth medium (Keating et al., 1996). AcpS is the only factor that maintains the ACP pool in its holo form, implying a possible regulatory function of AcpS on FAS II.

AcpS belongs to the phosphopantetheine transferase (PPT) family of proteins, binds $\mathrm{CoA}$ and its derivatives and requires magnesium for activity (Carreras et al., 1997; Lambalot et al., 1996). The PPT-family proteins are divided into three different groups based on sequence motifs and structural features (Mootz et al., 2001). Bacterial PPTs are 120-residue trimeric enzymes and belong to the group I PPTs (PPT I; Parris et al., 2000; Chirgadze et al., 2000; Dym et al., 2009). B. subtilis Sfp (surfactin-producing protein) and human AcpS represent the group II PPTs (PPT II; Quadri et al., 1998; Mofid et al., 2004; Reuter et al., 1999; Bunkoczi et al., 2007). The two domains of monomeric PPT II are similar to the two adjacent monomers in the trimeric PPT I. The group III PPTs (PPT III) comprise transferases that are an integral part of yeast and fungal FAS I (Leibundgut et al., 2008; Jenni et al., 2007; Lomakin et al., 2007).
AcpS represents an important link in FAS II regulation and hence is a possible drug target for combating bacterial infections. AcpS is essential for the viability of M. smegmatis and inhibitors of AcpS have recently been reported (Chalut et al., 2006; Chu et al., 2003; Gilbert et al., 2004). While a number of crystal structures of bacterial AcpSs are available, the mechanism of the transferase activity and its inhibition are not entirely understood. The high-resolution X-ray structures of AcpS from S. aureus $\left(\mathrm{AcpS}_{\mathrm{SA}}\right)$, V. cholerae $\left(\mathrm{AcpS}_{\mathrm{VC}}\right)$ and B. anthracis $\left(\mathrm{AcpS}_{\mathrm{BA}}\right)$ reported here contribute to the understanding of the general structural and mechanistic details of the pathogenic AcpS-catalyzed reaction and suggest a strategy for inhibition.

\section{Materials and methods}

\subsection{Protein cloning, expression and purification}

$\mathrm{AcpS}_{\mathrm{SA}}, \mathrm{AcpS}_{\mathrm{VC}}$ and $\mathrm{AcpS}_{\mathrm{BA}}$ were cloned into the pMCSG7 vector with an N-terminal six-His tag, expressed in E. coli BL21-CodonPlus(DE3) cells and purified using the immobilized metal-affinity chromatography technique as described previously (Gräslund et al., 2008). $\mathrm{AcpS}_{\mathrm{BA}}$ and $\mathrm{AcpS}_{\mathrm{VC}}$ were expressed, purified and crystallized as SeMet proteins following well established procedures (Kim et al., 2004). Dynamic light scattering and analytical gel filtration were used to analyze the homogeneity and the oligomerization state of the proteins.

\subsection{Crystallization}

Prior to crystallization trials, the proteins were stored in $10 \mathrm{~m} M$ Tris- $\mathrm{HCl} \mathrm{pH} 8.3,500 \mathrm{~m} M \mathrm{NaCl}, 5 \mathrm{~m} M \beta$-mercaptoethanol (BME) (AcpS $\left.\mathrm{SA}_{\mathrm{SA}}\right), 20 \mathrm{~m} M$ HEPES pH 8.0, $200 \mathrm{~m} M$ $\mathrm{NaCl}, 1 \mathrm{~m} M$ dithiothreitol (DTT) (AcpS $\mathrm{VC}_{\mathrm{V}}$ ) and $10 \mathrm{~m} M$ HEPES pH 7.5, $300 \mathrm{~m} M \mathrm{NaCl}, 0.5 \mathrm{~m} M$ tris(2-carboxyethyl)phosphine (TCEP) $\left(\mathrm{AcpS}_{\mathrm{BA}}\right)$ at $193 \mathrm{~K}$. The proteins were crystallized with and without CoA using the sitting-drop vapor-diffusion technique and commercially available crystallization screens from Qiagen (Valencia, California, USA) or optimized sparse-matrix crystallization screens (University of Toronto). Crystals suitable for structure determination were obtained under the following conditions: $800 \mathrm{~m} M$ succinate $\mathrm{pH} 7.0$ at $295 \mathrm{~K}_{\text {for }} \mathrm{AcpS}_{\mathrm{SA}}\left(7.3 \mathrm{mg} \mathrm{ml}^{-1}\right), 25 \%$ PEG 3350, $200 \mathrm{~m} M \mathrm{MgCl}, 100 \mathrm{~m} M$ HEPES pH 7.5, $10 \mathrm{~m} M$ CoA at $295 \mathrm{~K}$ for $\mathrm{AcpS}_{\mathrm{BA}}\left(13.8 \mathrm{mg} \mathrm{ml}^{-1}\right)$ and $30 \% \mathrm{MPD}, 100 \mathrm{mM}$ sodium acetate $\mathrm{pH} 4.6,20 \mathrm{~m} M \mathrm{CaCl}_{2}, 10 \mathrm{~m} M \mathrm{CoA}$ at $289 \mathrm{~K}$ for $\mathrm{AcpS}_{\mathrm{VC}}\left(55 \mathrm{mg} \mathrm{ml}^{-1}\right)$. Cryoprotection was performed using $25 \%$ sucrose for $\mathrm{AcpS}_{\mathrm{SA}}, 5 \%$ glycerol, $5 \%$ sucrose, $5 \%$ ethylene glycol in magic solution, Paratone for $\mathrm{AcpS}_{\mathrm{BA}}$ and $10 \%$ glycerol, 30\% MPD, $100 \mathrm{~m} M$ sodium acetate $\mathrm{pH} 4.6,20 \mathrm{~m} M$ $\mathrm{CaCl}_{2}$ for $\mathrm{AcpS}_{\mathrm{VC}}$.

\subsection{Structure determination}

$\mathrm{X}$-ray data were collected on the Life Science Collaborative Access Team (LS-CAT) 21-ID-F $\left(\mathrm{AcpS}_{\mathrm{SA}}\right.$ and $\left.\mathrm{AcpS}_{\mathrm{BA}}\right)$ and the Structural Biology Center (SBC) 19-ID (AcpS $\mathrm{VC}$ ) beamlines at the Advanced Photon Source, Argonne National 
Laboratory, USA. Diffraction images for the deposited structures are available at the CSGID website (http://www.csgid.org/ csgid/pages/home). Data sets were processed with $H K L-2000$ (Otwinowski \& Minor, 1997; $\mathrm{AcpS}_{\mathrm{BA}}$ ) and $H K L-3000$ (Minor et al., 2006; $\mathrm{AcpS}_{\mathrm{SA}}$ and $\left.\mathrm{AcpS}_{\mathrm{VC}}\right)$. Initial structure solutions for $\mathrm{AcpS}_{\mathrm{SA}}$ and $\mathrm{AcpS}_{\mathrm{BA}}$ were obtained using Phaser (McCoy et al., 2007) from the $C C P 4$ package (Winn et al., 2011) using the B. subtilis AcpS structure (PDB entry 1f71; Parris et al., 2000) and the structure of $\mathrm{AcpS}_{\mathrm{SA}}$ (PDB entry 3f09), respectively, as the molecular-replacement model. The models were rebuilt with ARP/wARP (Morris et al., 2003). The structure of $\mathrm{AcpS}_{\mathrm{VC}}$ was determined by single-wavelength anomalous dispersion (SAD) using the automated phasing and model-building option in the HKL-3000 suite (Minor et al., 2006). Although 48 Se sites were expected, 61 Se sites were found by SHELXD (Sheldrick, 2008) because some N-terminal SeMet sites were found to have multiple sites. Phasing was carried out by MLPHARE (Otwinowski, 1991) with a final overall phasing power of 1.15 to $1.85 \AA$ resolution and the phases were improved by density modification (DM; Cowtan, 1994; Supplementary Fig. 1). Initial model building was performed with Buccaneer (Cowtan, 2006) and subsequent manual adjustments used Coot (Emsley \& Cowtan, 2004) to complete the first model of $\mathrm{AcpS}_{\mathrm{VC}}$ with a total of 3014 amino acids (out of 3096). The initial models were refined with REFMAC v.5.5 (Murshudov et al., 2011; $\mathrm{AcpS}_{\mathrm{SA}}$ and $\mathrm{AcpS}_{\mathrm{BA}}$ ) and phenix.refine (Adams et al., 2010; $\mathrm{AcpS}_{\mathrm{VC}}$ ) with manual adjustments in Coot (Emsley $\&$ Cowtan, 2004). The quality of the final models was checked with the PDB validation server ( $A D I T$ validation server; http://deposit.pdb.org/validate/) and MolProbity (Davis et al., 2007; Chen et al., 2010). Data collection and refinement statistics for all three proteins are given in Table 1. The pairwise structural alignments were performed with the DaliLite server (Holm \& Park, 2000). The structural figures were generated using PyMOL (DeLano, 2002) and LigPlot $^{+}$v.1.3 (Wallace et al., 1995).

\footnotetext{
${ }^{1}$ Supplementary material has been deposited in the IUCr electronic archive (Reference: DW5015). Services for accessing this material are described at the back of the journal.
}

\section{Results}

\subsection{Overall tertiary and quaternary structure of bacterial AcpS}

The investigated AcpS enzymes share about 50\% sequence identity and all form functional trimers in the crystal with a comparable total buried surface area of $\sim 4500-5060 \AA^{2}$ (Figs. $1 a$ and $1 b$ ). Dynamic light scattering and analytical sizeexclusion chromatography (data not shown) are consistent with the crystallographic data on oligomerization. The three proteins are structurally very similar, with root-mean-square deviations (r.m.s.d.s) of $0.14-0.90$ and $1.1-1.5 \AA$ in the $\mathrm{C}^{\alpha}$ atom positions of the chains within and between the three species, respectively. The AcpS monomer has an elongated elliptical shape and possesses an $\alpha / \beta$ fold. The longest helix, $\alpha 4$, is wrapped by a three-stranded antiparallel $\beta$-sheet, five shorter helices and two $\beta$-strands (Figs. $1 c$ and $1 d$ ). Seven of the 14 residues of the $\beta$-sheet that are buried in the interior of every ApcS trimer are hydrophobic (Fig. 1c). Hydrophilic interactions also contribute to trimerization. $\mathrm{AcpS}_{\mathrm{SA}}$ and $\mathrm{AcpS}_{\mathrm{BA}}$ lack helix $\alpha 6$ (residues 92-101) of $\mathrm{AcpS}_{\mathrm{VC}}$ (Fig. 1d).

\subsection{Crystal structure of $S$. aureus apo-AcpS}

13 residues in molecule $A(\mathrm{MOL} \mathrm{A})$, four residues in molecule $B$ (MOL B) and three residues in molecule $C$ (MOL C) of the 24-residue $\mathrm{N}$-terminal purification tag were modeled. The purification tag of MOL A in one trimer docks 


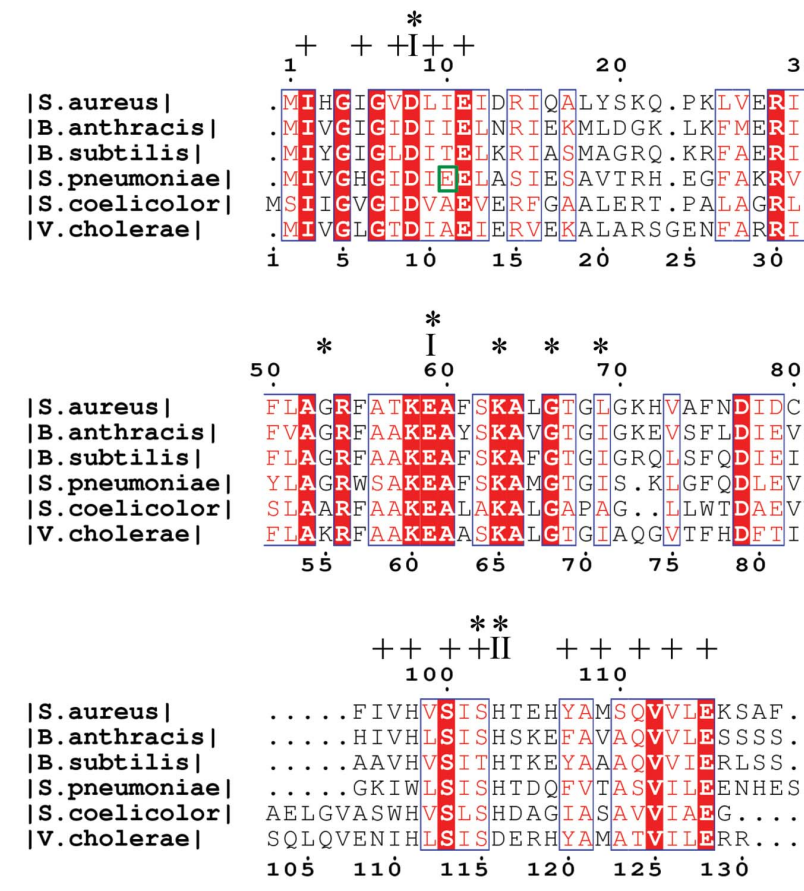

(a)

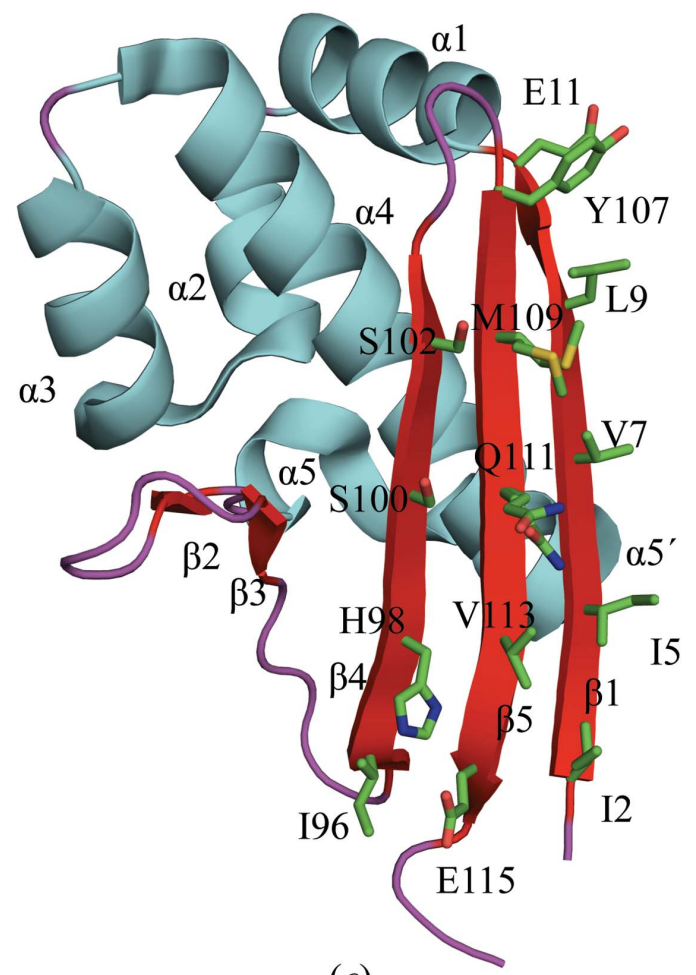

(c)

$* \quad *$
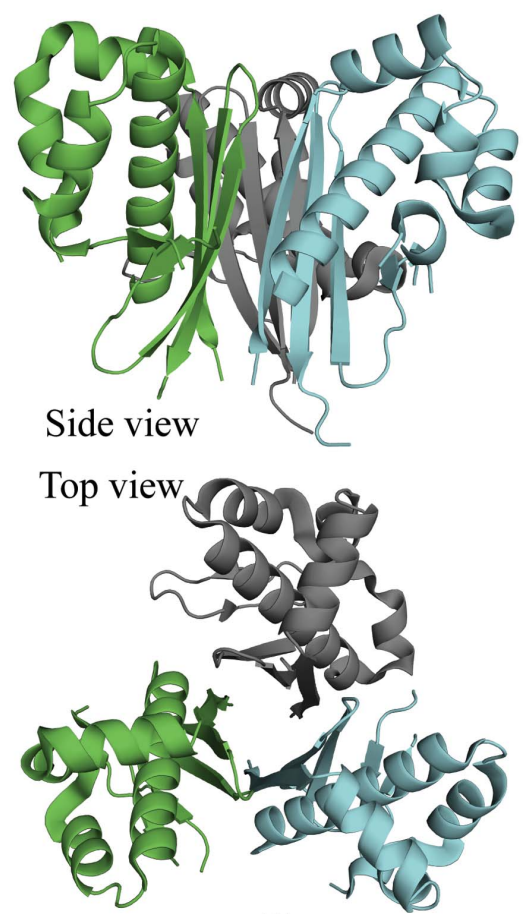

(b)

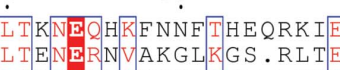
TRSEIL Q Y Y E LSEK . RKN IESTILIPGGERRG . . VVA $\begin{array}{lll}3 \dot{5} & 4 \dot{O} & 4 \dot{5}\end{array}$

90

CYNDELGKPK, TDYEG . . . . . IRKD QNGKPY I I C T KLS $Q .$.

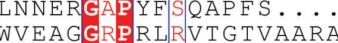
作 $95 \dot{0} 10 \dot{0}$

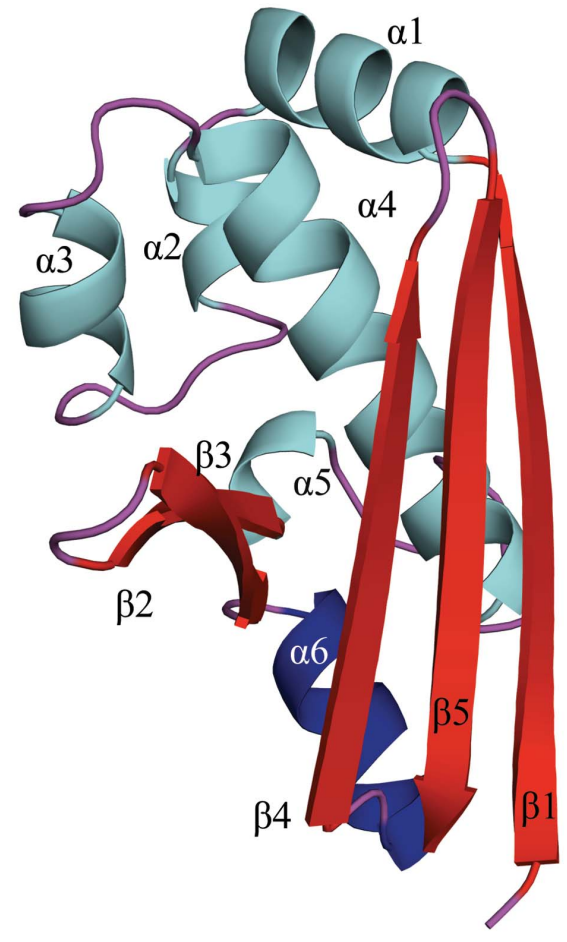

(d)

Figure 1

Bacterial AcpS. (a) Multiple sequence alignment of some bacterial AcpS enzymes with known X-ray structures: $S$. aureus (PDB entry 3f09), B. anthracis (PDB entry 3hyk), B. subtilis (PDB entry 1f7l), S. pneumoniae (PDB entry $1 \mathrm{fth}$ ), V. cholerae (PDB entry 3qmn) and S. coelicolor (PDB entry 2jbz). The conserved residues are shaded red and similar residues are displayed in red letters. Residues of the central $\beta$-sheet of AcpS $\mathrm{SA}_{\mathrm{SA}}$ numbered in $(c)$ are marked with a plus sign. Asterisks indicate residues of $\mathrm{AcpS}_{\mathrm{VC}}$ that coordinate $\mathrm{CoA} / \mathrm{K}$ (see Fig. $3 c$ ). The coordinators of two magnesium cations, Mg-I and Mg-II (see Figs. $4 d$ and $4 e$ ), are shown as I and II, respectively. The green box indicates the Glu-II position, an alternative glutamate of the group II and III PPTs that is involved in coordination of Mg-I. Multiple sequence alignment was performed by ClustalW (available at http://www.genome.jp/tools/ clustalw) and the figure was generated with ESPript2.2 (Gouet et al., 1999). (b) The quaternary structure of the AcpS enzyme (apo-AcpS $\mathrm{SA}_{\mathrm{S}}$ is shown). (c) The tertiary structure of a single polypeptide of $\mathrm{AcpS}_{\mathrm{SA}}$. The residues (in green) of the central $\beta$-sheet that are exposed to the interior of AcpS trimer are numbered according to the sequence of $\operatorname{AcpS}_{\mathrm{SA}}(d)$ Monomer of $\mathrm{AcpS}_{\mathrm{VC}}$ with the structurally distinct helix $\alpha 6$ in dark blue. 
onto a solvent-exposed hydrophobic patch that is formed by residues of helices $\alpha 1, \alpha 2$ and $\alpha 4$ of a symmetry-related molecule $C$ (SYM C) (Fig. 2). The helical part of the tag is positioned above helix $\alpha 5$ and between helices $\alpha 2$ and $\alpha 5^{\prime}$ of SYM C, interacting with the side chains of these structural elements (Fig. 2). The dipole moment of helix $\alpha 5^{\prime}$ may have a weak stabilizing effect on the helical portion of the tag. Glu84 and Leu85 of MOL C contribute to the interaction by contacting helix $\alpha 5^{\prime}$ of SYM C (Fig. 2), while both of these amino-acid residues are disordered in chain $A$. Leu85 is ordered and Glu84 is not observed in the electron density in chain $B$.

\subsection{Crystal structure of $V$. cholerae AcpS in complex with CoA}

24 polypeptide chains of $\mathrm{AcpS}_{\mathrm{VC}}$ are arranged in eight trimers in the $P 2_{1}$ asymmetric unit. Three molecules of CoA were modeled per trimer. Each $\mathrm{CoA}$ interacts with the two adjacent protein subunits in every trimer (Fig. $3 a$ ). The electron density of the entire CoA is clearly defined in six of the 24 CoAs (Fig. 3b). In the remaining 18 CoAs either the P-pant group has traces of density or, for the CoA P-pant group in chain $N(\mathrm{CoA} / \mathrm{N})$, no density was observed (Fig. $3 b)$. For this reason, a $3^{\prime}, 5^{\prime}$-ADP molecule was modeled with an occupancy of 0.2 at this binding site (Fig. $3 b$ ). The pantothenate parts of all CoAs have two kinks of $\sim 100-110^{\circ}$ that might be forced by intramolecular and intermolecular protein-ligand contacts.

The coordination of $\mathrm{CoA}$ in chain $K(\mathrm{CoA} / \mathrm{K})$ is described here because it has well defined density for the entire ligand (Fig. 3c). The adenine ring of $\mathrm{CoA} / \mathrm{K}$ is placed between the $\mathrm{N}$-terminus of strand $\beta 3$ of AcpS chain $K(\mathrm{AcpS} / \mathrm{K})$ and the C-terminus of helix $\alpha 4$ of AcpS chain $J(\mathrm{AcpS} / \mathrm{J})$, making interactions with Leu83 of chain $K($ Leu83/K) and Gly64 of chain $J$ (Figs. $3 a$ and $3 c$ ). The ribose ring does not make hydrogen bonds to the protein and its $2^{\prime}-\mathrm{OH}$ group points toward the hydrophobic Pro86 and Ile110 of AcpS/K (Fig. 3c). The $3^{\prime}$-phosphate group $\left(3^{\prime}-\mathrm{P}\right)$ interacts with the side chains

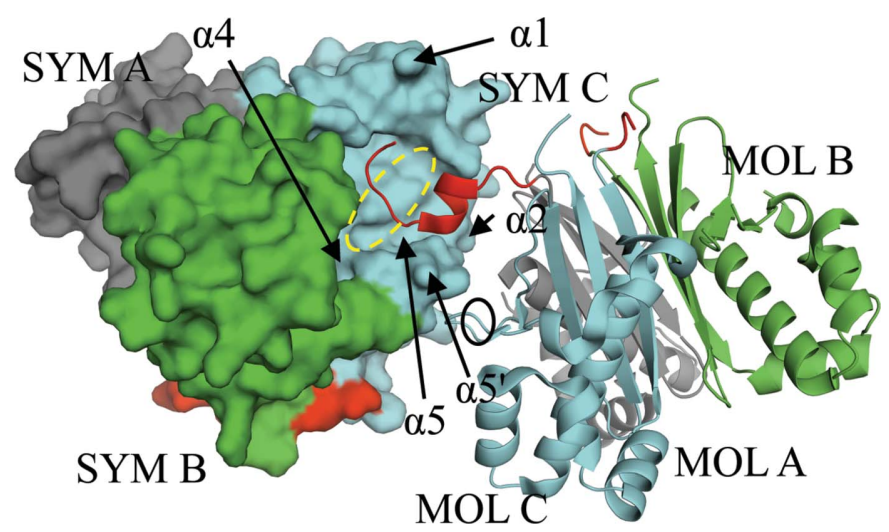

\section{Figure 2}

Purification tag of $\mathrm{AcpS}_{\mathrm{SA}}$ in the CoA-binding site. The symmetry-related trimer is shown in surface representation. The trimer of the asymmetric unit is shown in ribbon representation. The 24-residue purification tag (red) and residues 83-84 (black oval) that stabilize the $\alpha 5^{\prime}$-helix of SYM $\mathrm{C}$ are shown. A dashed yellow oval visualizes the binding area of the P-pant portion of CoA. of Lys51 and His80 (Fig. 3c) of AcpS/K. The pyrophosphate moiety of CoA is anchored by interactions with Ser111/K and Asp112/K and with Asp8, Glu57 (through $\mathrm{Ca}^{2+}$ ) and Lys61 of AcpS/J (Fig. 3c). Calcium cations with occupancies of between 0.6 and 1.0 were modeled at two different sites, Ca-I and $\mathrm{Ca}-\mathrm{II}$, in the vicinity of every CoA (Figs. $3 d$ and $3 e$ ) except $\mathrm{CoA} / \mathrm{N}$. The calcium peaks were identified firstly by the presence of $20 \mathrm{mM} \mathrm{CaCl}$ in the crystallization condition and secondly by the coordination geometry of these peaks.

\subsection{Unusual 3', $\mathbf{5}^{\prime}$-ADP form of $B$. anthracis AcpS}

Analysis of the initial $2 F_{\mathrm{o}}-F_{\mathrm{c}}$ and $F_{\mathrm{o}}-F_{\mathrm{c}}$ electron-density maps at each coenzyme-binding site of the $\mathrm{AcpS}_{\mathrm{BA}}$ structure revealed the presence of two $3^{\prime}, 5^{\prime}$-ADP product molecules instead of the cocrystallized CoA (Fig. 4a). Hydrolysis of CoA in the crystal or the crystallization mother liquor was possible owing to the presence of $200 \mathrm{mM} \mathrm{MgCl}$ in the crystallization condition. The binding of one $3^{\prime}, 5^{\prime}$-ADP molecule $\left(\mathrm{ADP}_{\mathrm{I}}\right)$ is similar to the adenosine diphosphate (ADP) portion of CoA in the binary CoA-AcpS complex structures [PDB entries 1f71 (Parris et al., 2000), 3qmn and 2jbz (Dall'aglio et al., 2011)] and of $3^{\prime}, 5^{\prime}$-ADP in the 2qg8 (Structural Genomics Consortium, unpublished work) and $1 \mathrm{fth}$ (Chirgadze et al., 2000) structures (Fig. 4b). The position of the second $3^{\prime}, 5^{\prime}-\mathrm{ADP}\left(\mathrm{ADP}_{\mathrm{II}}\right)$ is described for the first time here (Fig. $4 c$ ).

The $\mathrm{N} 6$ atom of the adenine ring of $\mathrm{ADP}_{\mathrm{I}}$ makes hydrogen bonds to the backbone carbonyl $\mathrm{O}$ atoms of Arg84 of one monomer and Gly65 of the adjacent monomer in the trimer (Fig. 4b). Residues Arg45, Arg53, Asn81 and His103 surround the 3'-P group of every $\mathrm{ADP}_{\mathrm{I}}$, while residues Asp8, Glu58, Lys62, Ser102 and His103 interact with the $5^{\prime}$-phosphate group (5'-P; Fig. 4b). ADP ${ }_{\text {II }}$ interacts with Arg14 and Arg28 of one monomer of the trimer (Fig. 4c) and Lys70, Glu71 and Arg84 of a symmetry-related trimer (not shown).

Three magnesium cations, Mg-I, Mg-II and Mg-III, were modeled around the $5^{\prime}-\mathrm{P}$ group of each $\mathrm{ADP}_{\mathrm{I}}$ (Figs. $4 d, 4 e$ and $4 f)$. The identity of the magnesium peaks was identified firstly by the presence of $200 \mathrm{mM} \mathrm{MgCl}$ in the crystallization condition and secondly by the coordination geometry and the distances to the coordinating atoms. The positions of Mg-I and $\mathrm{Mg}$-II coincide with those in the $\mathrm{AcpS}_{\mathrm{PY}}$ structure (PDB entry 2qg8; Vedadi et al., 2007) and those of the calcium cations in the 3qmn structure. Mg-III facilitates the $\mathrm{ADP}_{\mathrm{I}}-\mathrm{ADP}_{\mathrm{II}}$ interaction. The $5^{\prime}-\mathrm{P}$ of $\mathrm{ADP}_{\mathrm{I}}$ and the $3^{\prime}-\mathrm{P}$ of $\mathrm{ADP}_{\mathrm{II}}$ both interact with $\mathrm{Mg}-\mathrm{III}$, so that the distance between the $\mathrm{O} 4 \mathrm{P}$ atom of the $5^{\prime}-\mathrm{P}$ and the $\mathrm{O} 3 \mathrm{P}$ atom of the $3^{\prime}-\mathrm{P}$ is $\sim 2.8 \AA$ (Fig. $4 f$ ).

\section{Discussion}

\subsection{Overall structural comparison of AcpS}

The residues that are involved in the activity and oligomerization of bacterial AcpS are highly conserved (Figs. 1a, $5 a$ and $5 b$ ). The partially hydrophobic surface of the threestranded antiparallel $\beta$-sheet is considered to be the main reason why bacterial AcpS forms trimers (Fig. 1b). Polar 


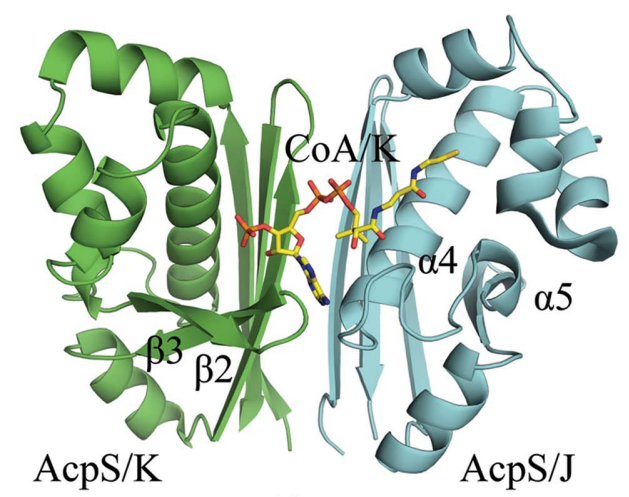

(a)

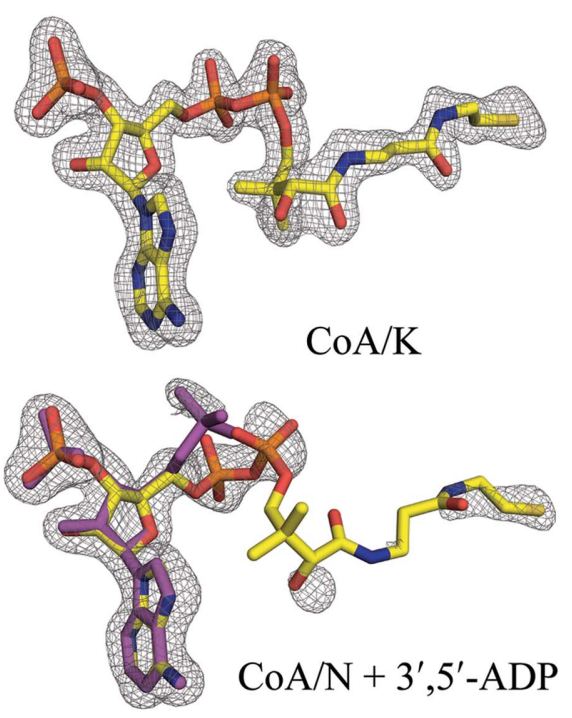

(b)

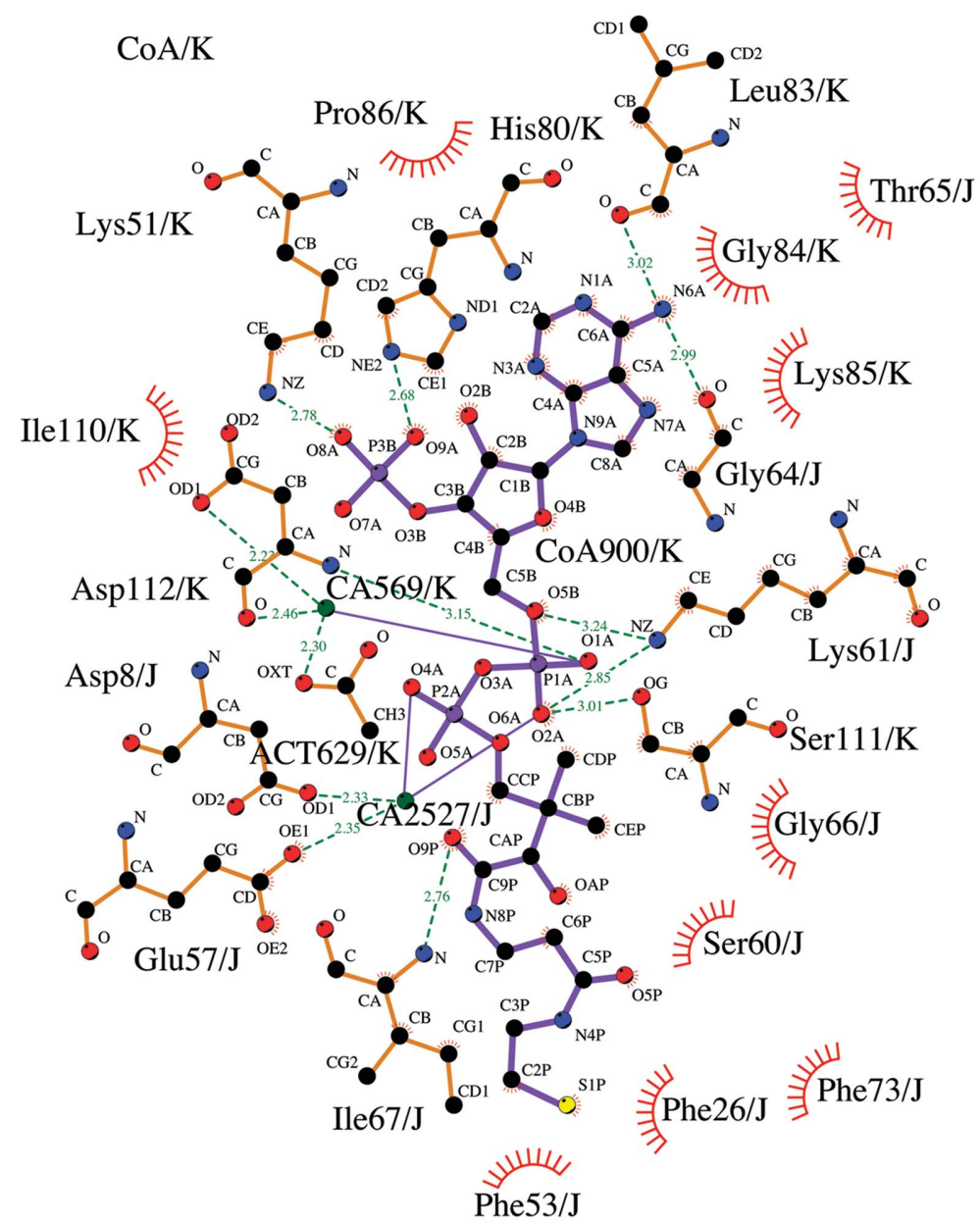

(c)

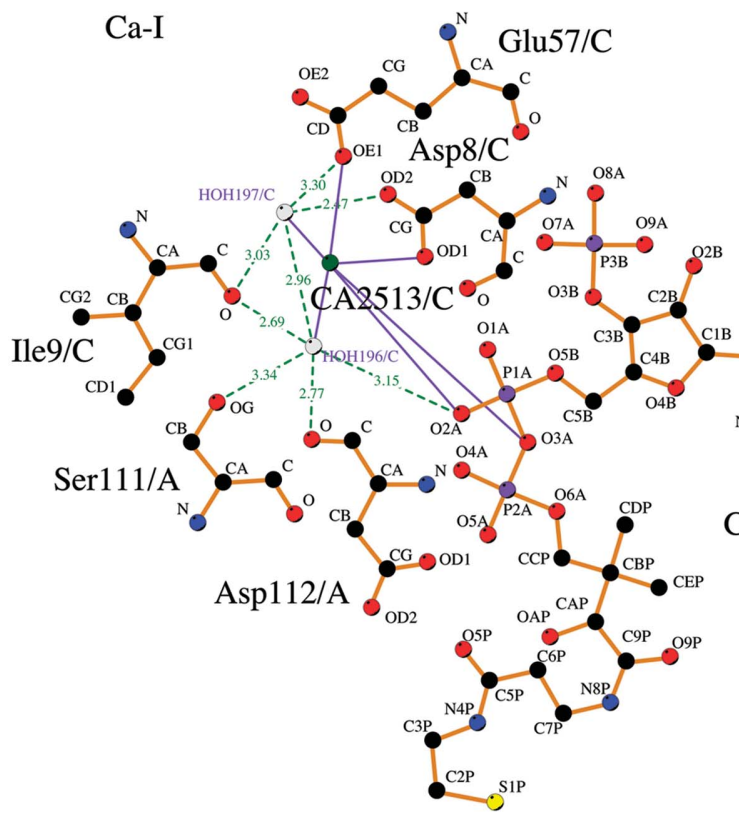

$(d)$

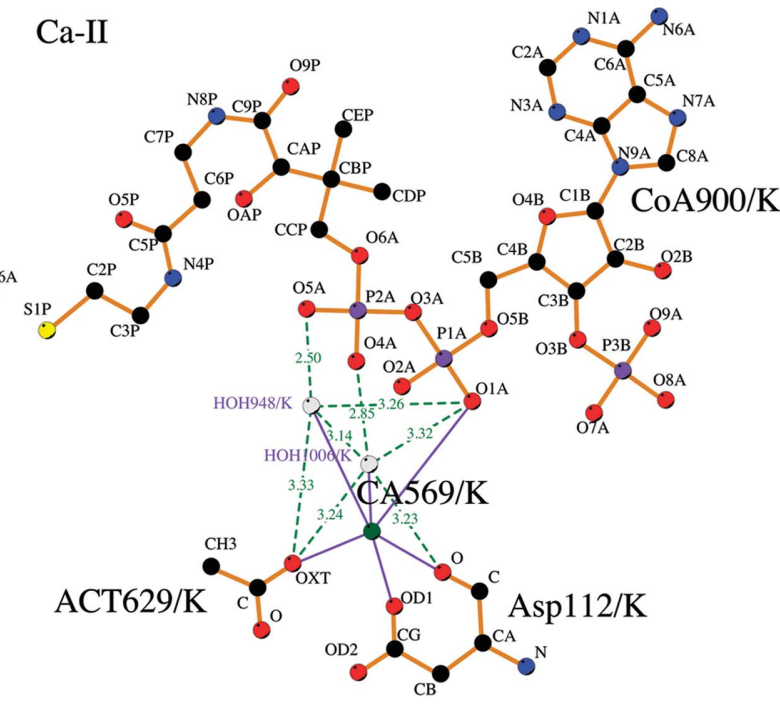

(e)

Figure 3

The structure of the binary $\mathrm{CoA}-\mathrm{AcpS}_{\mathrm{VC}}$ complex. (a) Interaction of $\mathrm{CoA} / \mathrm{K}$ at the interface of the AcpS/K and AcpS/J protein molecules of the $\mathrm{AcpS}_{\mathrm{VC}} / \mathrm{J} / \mathrm{K} / \mathrm{L}$ trimer. $\mathrm{CoA}$ is colored according to its atoms: $\mathrm{C}$, light yellow; N, blue; $\mathrm{O}$, red; $\mathrm{P}$, orange; $\mathrm{S}$, dark yellow. $(b)$ Examples of CoA molecules with well defined $(\mathrm{CoA} / \mathrm{K})$ and poorly defined $(\mathrm{CoA} / \mathrm{N})$ electron densities. The $2 F_{\mathrm{o}}-F_{\mathrm{c}}$ maps are contoured at $1.0 \sigma$. The modeled $3^{\prime}, 5^{\prime}-\mathrm{ADP}$ molecule at the $\mathrm{CoA} / \mathrm{N}$ binding site is shown as purple sticks. $(c)$ Coordination of $\mathrm{CoA} / \mathrm{K}$. $(d)$ and $(e)$ show the two calcium-binding sites, Ca-I and Ca-II. The coordination of CA2513/C in $(d)$ is equivalent to that of CA2527/J in (c). 


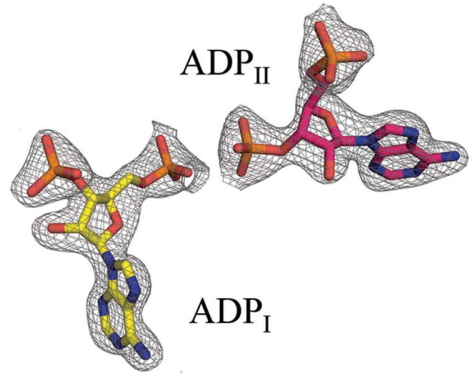

(a)

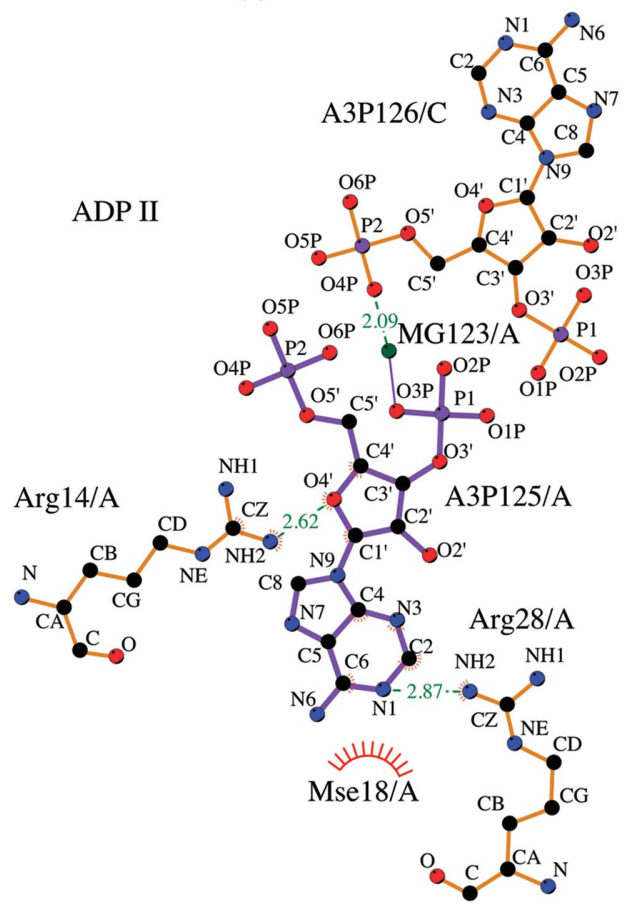

(c)

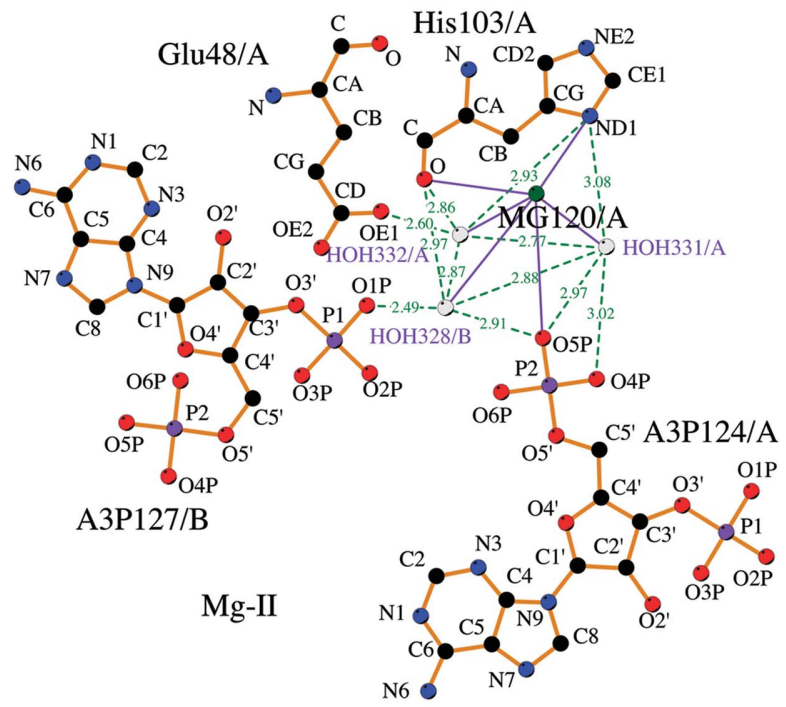

(e)

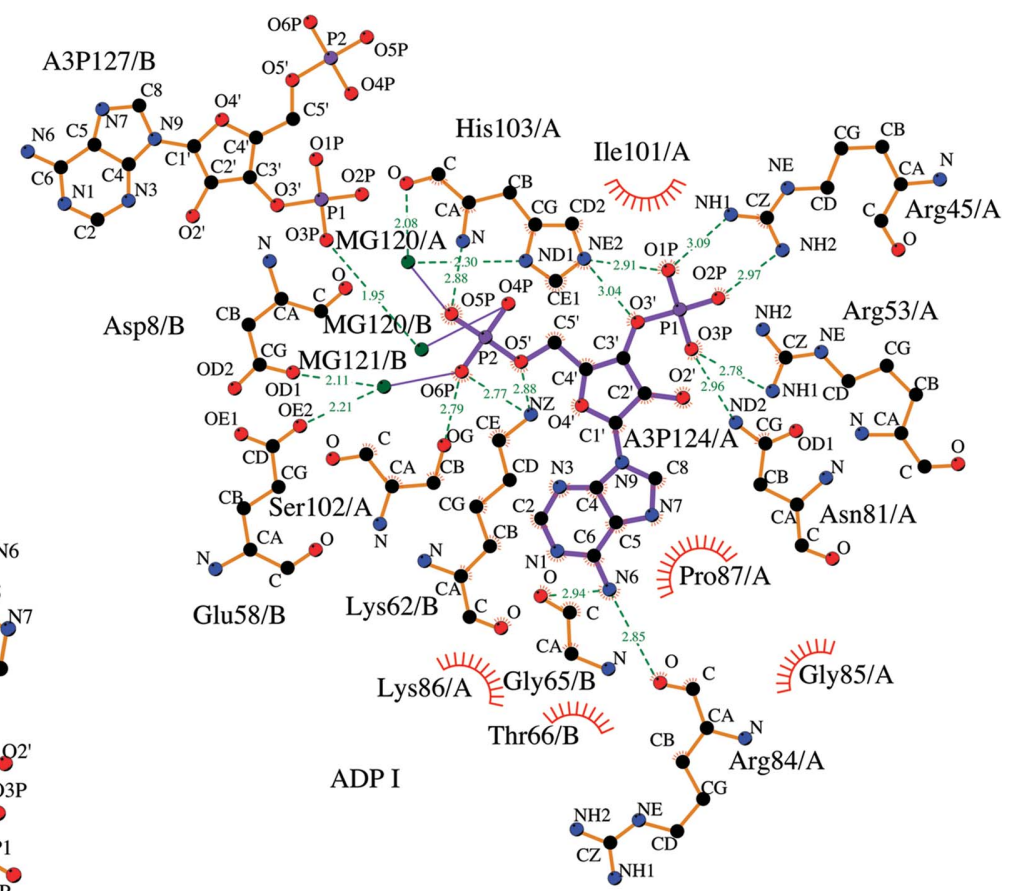

(b)

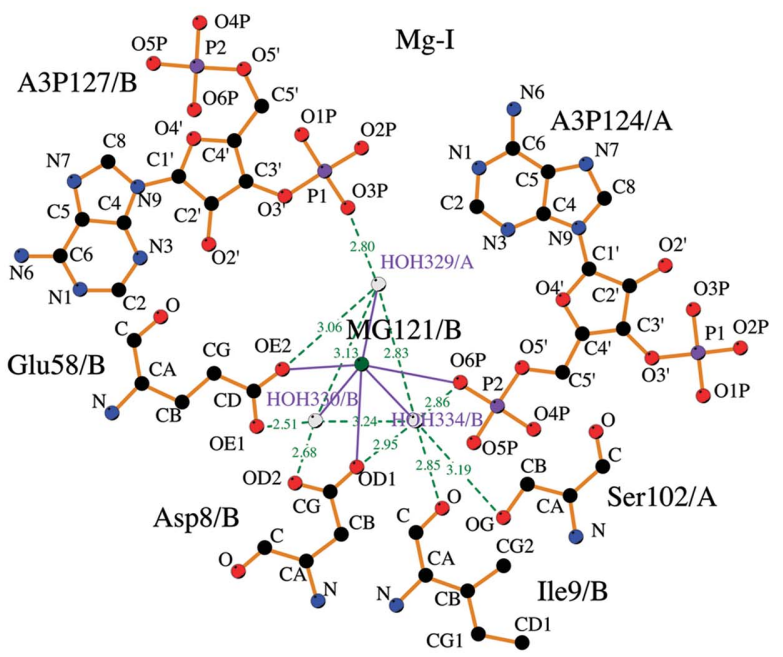

(d)

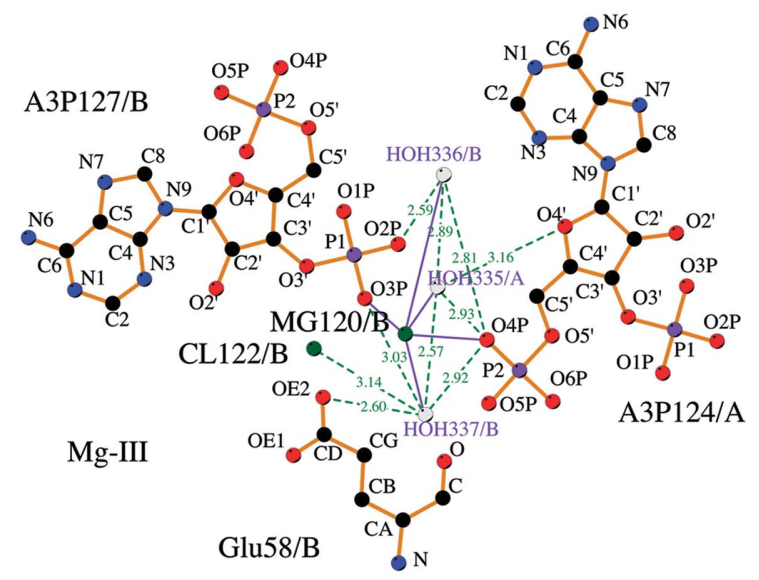

$(f)$

Figure 4

Products of CoA hydrolysis by ACP-free $\operatorname{AcpS}_{\mathrm{BA}}$. (a) The $3.0 \sigma$ OMIT map of the two $3^{\prime}, 5^{\prime}$-ADP molecules, $\mathrm{ADP}_{\mathrm{I}}$ and $\mathrm{ADP}_{\mathrm{II}}$, modeled at each of the three CoA-binding sites. $(b, c)$ Binding pockets of $\mathrm{ADP}_{\mathrm{I}}$ and $\mathrm{ADP}_{\mathrm{II}}(d),(e)$ and $(f)$ show the $\mathrm{Mg}$-I, $\mathrm{Mg}$-II and $\mathrm{Mg}$-III binding sites. 
contacts between adjacent AcpS monomers in a trimer also contribute to oligomerization. Differences between the AcpS structures lie outside the regions that are required for trimerization, are species-specific and their functional consequences, if any, remain to be investigated. The residues between strand $\beta 3$ and strand $\beta 4$ in the structures of $A c p S_{\mathrm{VC}}$, Streptomyces coelicolor AcpS ( $\mathrm{AcpS}_{\mathrm{Sc}}$; PDB entries $2 \mathrm{jca}$ and 2jbz; Dall'aglio et al., 2011) and Plasmodium yoelii AcpS $\left(\mathrm{AcpS}_{\mathrm{PY}}\right.$; PDB entries 2bdd and 2qg8; Vedadi et al., 2007) form an $\alpha$-helix, while they adopt a loop conformation in the structures of AcpS $\mathrm{SA}, \mathrm{AcpS}_{\mathrm{BA}}$ and other AcpSs (PDB entries 1f7t and 1fte; Parris et al., 2000; Chirgadze et al., 2000; Figs. $1 c, 1 d$ and 5c).

The synthases do not undergo overall structural changes upon association/dissociation of CoA and ACP; however, conformational perturbations do occur at their easily accessible binding sites and in the close vicinity. The solvent-exposed loops $\alpha 1-\alpha 2, \alpha 3-\alpha 4, \beta 2-\beta 3$ and $\alpha 4-\alpha 5\left(\alpha 5^{\prime}\right)$ and the adjacent termini of the respective helices/strands of known AcpS structures can be disordered in the absence of CoA, ACP, small molecules and crystal-packing forces. However, despite the presence of $\mathrm{ACP}$ in the B. subtilis $\mathrm{AcpS}\left(\mathrm{AcpS}_{\mathrm{BS}}\right)$ structure (PDB entry 1f80; Parris et al., 2000), the loop residues still exhibit high $B$ factors in comparison to the central $\beta$-sheet of the synthase. Thus, the conformation of all of the aforementioned regions is linked to the presence of the AcpS substrates.

\subsection{Binding of the substrates}

The residues of the CoA-binding and ACP-binding sites are well conserved in the AcpS enzymes, which suggests a similar mode of association of the substrates and mechanism of the AcpS-catalyzed reaction (Figs. $1 a$ and $5 a$ ). The AcpS trimer binds three CoA molecules and three ACP molecules. The interface between two adjacent AcpS monomers serves as a docking area for both CoA and ACP.

The apo-AcpS $\mathrm{SA}_{\mathrm{SA}}$ structure reveals that the intact purification tag may interfere with the binding of CoA (Fig. 2). This could explain why no suitable crystals were obtained of the CoA-complexed tagged protein. Cleavage of the tag was inefficient for $\mathrm{AcpS}_{\mathrm{SA}}$, possibly owing to inaccessibility of the tobacco etch virus (TEV) cleavage site. Cocrystals of $\mathrm{CoA}$ and $\mathrm{AcpS}_{\mathrm{SA}}$ without the purification tag were also poorly ordered. Whether the purification tag was present or absent, crystals of apo-AcpS $\mathrm{BA}_{\mathrm{BA}}$

Figure 5 and apo- $-\mathrm{AcpS}_{\mathrm{VC}}$ only diffracted to low resolution. The structure of $\mathrm{AcpS}_{\mathrm{VC}}$ provides details of the interaction of CoA with the enzyme (Fig. 3c). The nucleotide portions of all CoA molecules in the 3qmn structure exhibit lower $B$ factors than the P-pant group. The high thermal factors and observed conformational diversity of the P-pant moiety can be explained by the mechanism of the reaction, in which accessibility of the group is essential. This has also been reported for other AcpSs (Reuter et al., 1999). AcpS BA $_{\text {A }}$ only gave well diffracting crystals when the protein had the tag removed and it was pre-incubated with CoA. However, the presence of

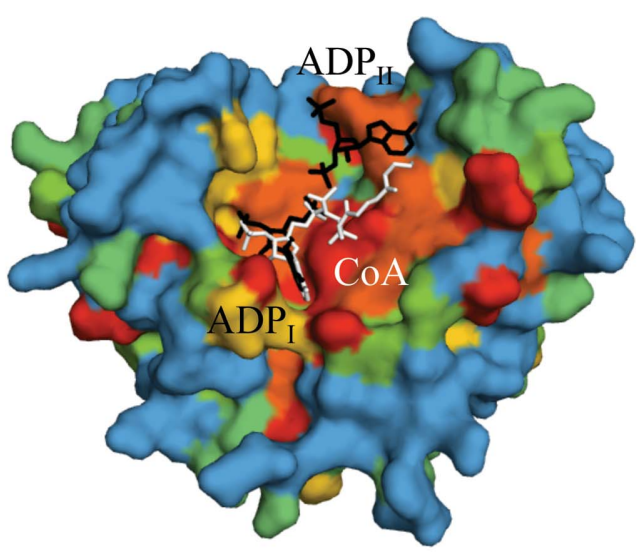

(a)
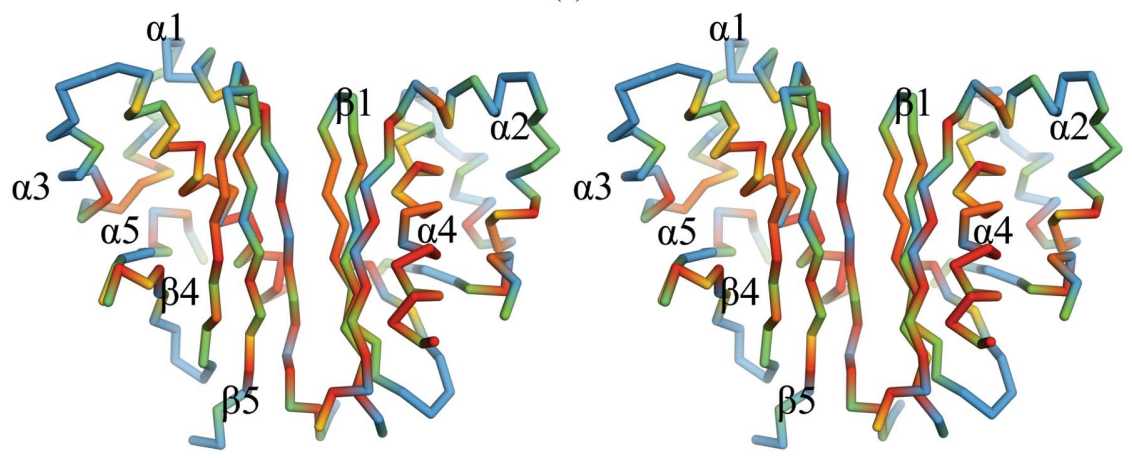

(b)
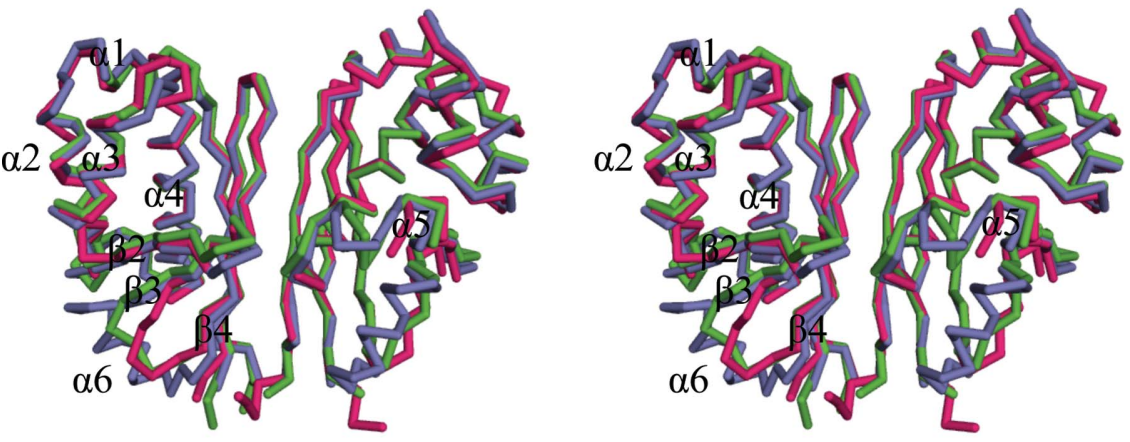

(c)

Structural comparison of bacterial AcpS. (a) Surface diagram of the sequence-based structural alignment of the bacterial AcpS enzymes presented in Fig. 1(a). The structure of apo-AcpS $\mathrm{SA}_{\mathrm{SA}}$ is used to display the conservation of the residues, which are colored from blue (variable) to red (100\% conserved). The positions of two 3',5'-ADP molecules (black) in $\mathrm{AcpS}_{\mathrm{BA}}$ and of CoA (white) in $\mathrm{AcpS}_{\mathrm{VC}}$ are shown. (b) Stereogram of the monomer-monomer interaction interface in the $\mathrm{AcpS}_{\mathrm{SA}}$ trimer. Residues are colored from blue (variable) to red (100\% conserved). The third molecule is omitted for clarity. (c) Stereogram of the least-squares superposition of the $\mathrm{AcpS}_{\mathrm{SA}}(\mathrm{red}), \mathrm{AcpS}_{\mathrm{VC}}$ (blue) and $\mathrm{AcpS}_{\mathrm{BA}}$ (green) structures. 
$200 \mathrm{mM} \mathrm{MgCl}$ in the crystallization condition appears to have been sufficient for the AcpS to hydrolyze the $10 \mathrm{~m} M$ CoA in the crystallization mixture even in the absence of ACP. Dym et al. (2009) have cocrystallized M. tuberculosis AcpS (AcpS MT; $_{\text {; }}$; PDB entry 3hqj) with CoA; however, they only modeled the $3^{\prime}, 5^{\prime}$-ADP part of the substrate and suggested that the P-pant moiety was disordered in the crystal. In contrast to all these other structures, the crystal structure of $\mathrm{AcpS}_{\mathrm{BA}}$ clearly shows two 3',5'-ADP molecules, $\mathrm{ADP}_{\mathrm{I}}$ and $\mathrm{ADP}_{\mathrm{II}}$, at each CoAbinding site (Fig. $4 a$ ). The $3^{\prime}$-P group of $\mathrm{ADP}_{\mathrm{I}}$, which represents the normally observed nucleotide site, in the $\mathrm{AcpS}_{\mathrm{BA}}$ structure makes hydrogen bonds to Arg45, Arg53, Asn81 and His103 (Fig. 4b). Moreover, the position of $\mathrm{ADP}_{\mathrm{I}}$ is additionally stabilized by three magnesium cations (Figs. $4 d$, $4 e$ and $4 f)$.

\subsection{Mechanism of the AcpS-catalyzed reaction}

The phosphopantetheinylation reaction proceeds in three steps: (i) deprotonation of the serine residue of ACP, (ii) $\mathrm{S}_{\mathrm{N}}$ 2-type nucleophilic attack of the deprotonated serine on the
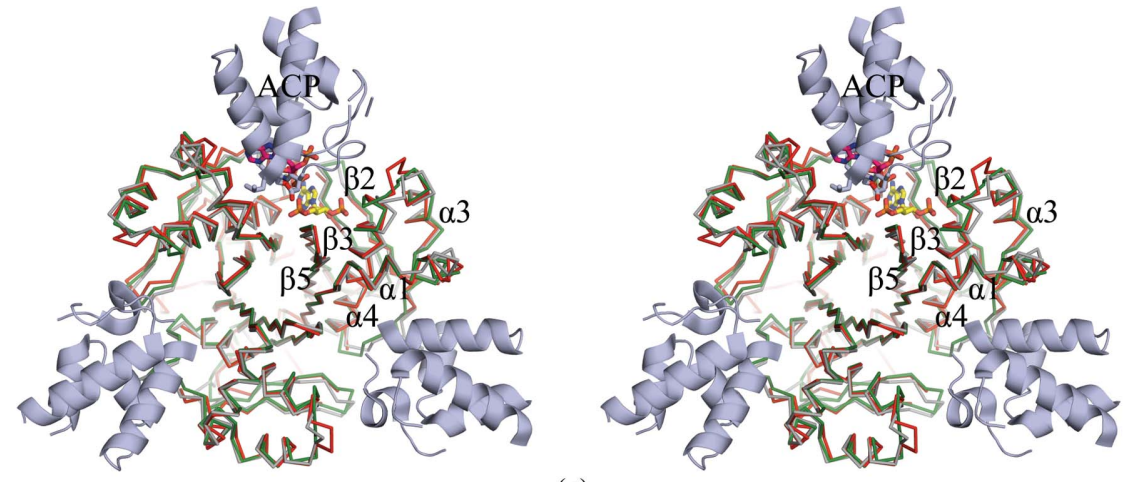

(a)

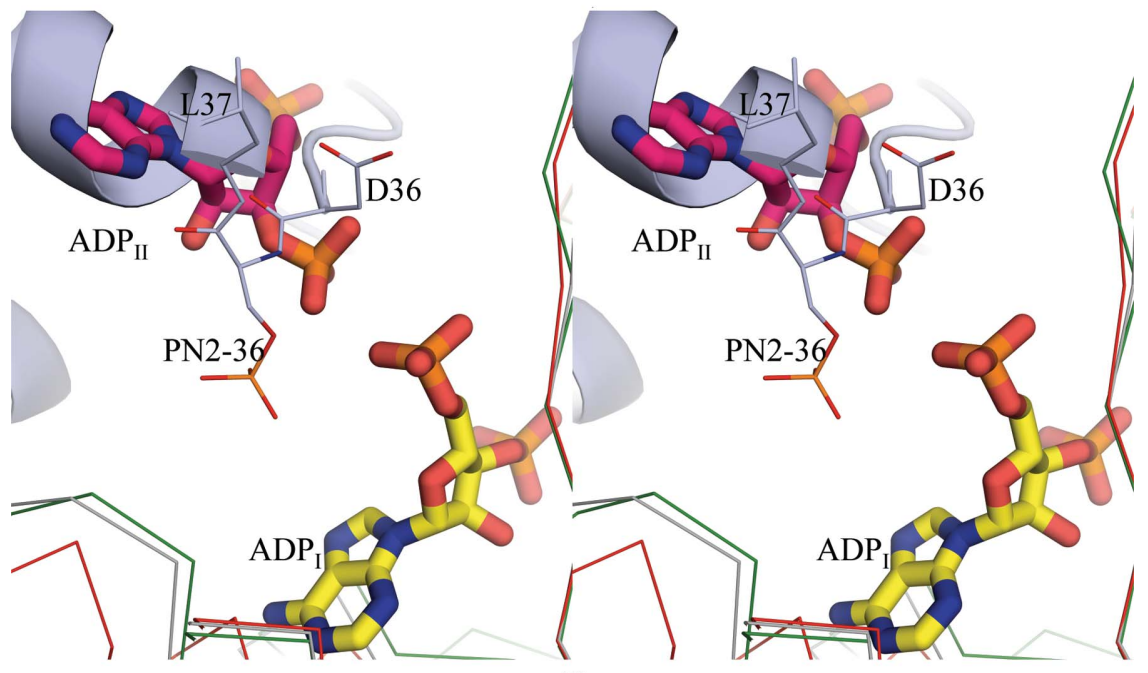

(b)

Figure 6

Modeling the bacterial AcpS-ACP complex. (a) Stereogram of the least-squares superposition of the $\mathrm{AcpS}_{\mathrm{SA}}$ (red), $\mathrm{AcpS}_{\mathrm{BA}}$ (green) and $\mathrm{AcpS}_{\mathrm{BS}}-\mathrm{ACP}_{\mathrm{BS}}$ (AcpS, black; ACP, light blue ribbon) structures. Two $3^{\prime}, 5^{\prime}$-ADP molecules in the $B$. anthracis structure are shown a sticks. (b) Stereo close-up view of $(a)$ showing $\mathrm{ADP}_{\mathrm{II}}$ in the $\mathrm{AcpS}_{\mathrm{BA}}$ structure clashing with the $\alpha 3$ helix of $\mathrm{ACP}_{\mathrm{BS}}$. Asp35, PN2-36 (P-pant-modified Ser36) and Leu37 of ACP are depicted as lines and colored by element: $\mathrm{C}$, blue; $\mathrm{O}$, red; $\mathrm{N}$, dark blue; $\mathrm{P}$, orange. $\beta$-phosphate of the bound CoA and (iii) protonation of the $\alpha$-phosphate of $3^{\prime}, 5^{\prime}$-ADP by a conserved lysine (Lys63 in $\mathrm{AcpS}_{\mathrm{SA}}$, Lys61 in $\mathrm{AspS}_{\mathrm{VC}}$ and Lys62 in AcpS $\mathrm{BA}$; Figs. $3 c$ and $4 b$ ) of AcpS (Johansson et al., 2009). The initial deprotonation step is achieved either by a water molecule, as in the group I PPT family (Parris et al., 2000), or by a glutamate residue, as in the group II PPT family (Bunkoczi et al., 2007). The preference for one or the other mechanism is determined by the coordination pattern of the $\mathrm{Mg}^{2+}$ denoted Mg-I (Fig. $4 d$ ). If an $\mathrm{Mg}$-bound hydroxide can activate a water molecule for nucleophilic attack, AcpS can hydrolyze CoA without the carrier protein (Parris et al., 2000). This might explain the absence of an intact cofactor in the $\mathrm{AcpS}_{\mathrm{BA}}$ structure even though the protein was cocrystallized with CoA. Binding of $\mathrm{Ca}^{2+}$ at the $\mathrm{Mg}-\mathrm{I}$ site in the $\mathrm{AcpS}_{\mathrm{VC}}$ structure (Fig. $3 d$ ) might lead to distortion of the active site and inability of the enzyme to hydrolyze CoA. However, calcium can function in catalysis: Parris et al. (2000) have demonstrated that the P-pant group is transferred from the $\mathrm{CoA}-\mathrm{AcpS}_{\mathrm{BS}}$ complex to $\mathrm{ACP}_{\mathrm{BS}}$, although at a reduced rate, if calcium is present. The modeled $3^{\prime}, 5^{\prime}-\mathrm{ADP}$ at the $\mathrm{CoA} / \mathrm{N}$ binding site of the $\mathrm{AcpS}_{\mathrm{VC}}$ structure is perhaps a result of slow hydrolytic activity in the absence of ACP (Fig. 3b).

Two different glutamate residues, Glu-I (conserved among all PPTs) and Glu-II (specific to the group II and III PPT) (Fig. $1 a)$, have been proposed to play a role in the deprotonation step. Substitution of Glu181 (Glu-I) caused a significant loss of human AcpS activity (Bunkoczi et al., 2007). Glu-I binds Mg-I through a metal-bound water molecule in the group I PPT AcpS MT $_{\text {(PDB }}$ entry 3hqj), but was suggested to not be involved in the deprotonation step (Dym et al., 2009). Dym et al. (2009) also suggested an alternative deprotonation scenario in $\mathrm{AcpS}_{\mathrm{MT}}$ owing to the presence of the second Mg-binding site and the specificity of the synthase. In the structures of $\mathrm{AcpS}_{\mathrm{BA}}$ and $\mathrm{AcpS}_{\mathrm{MT}}$ (PDB entry 3hqj) a magnesium cation is bound at this site, denoted Mg-II (Fig. 4e). A calcium cation was also modeled at this site in the $\mathrm{AcpS}_{\mathrm{VC}}$ structure (Fig. 3e). Many Mg-binding enzymes (reviewed in Black et al., 1994; Glusker et al., 2001) bind two magnesium cations at a distance of 3.6$6.3 \AA$ apart. Although one $\mathrm{Mg}^{2+}$ is considered to be a catalytic metal, the role of the second $\mathrm{Mg}^{2+}$ is unclear; it may contribute to the maintenance of structural integrity at the active site or may possibly lower the activation barrier of a reaction (Black et al., 1994). Mg-I and Mg-II are $5 \AA$ apart in the $\mathrm{AcpS}_{\mathrm{BA}}$ and $\mathrm{AcpS}_{\mathrm{MT}}$ structures. Mg-III is also a distance of $\sim 5 \AA$ from $\mathrm{Mg}$-I and $\mathrm{Mg}$-II and bridges $\mathrm{ADP}_{\mathrm{I}}$ and $\mathrm{ADP}_{\mathrm{II}}$ in the $\mathrm{AcpS}_{\mathrm{BA}}$ structure. The observation of this 
site is likely to be a consequence of the high concentration of the metal and the presence of the hydrolyzed product $3^{\prime}, 5^{\prime}$ ADP (Fig. 4f).

\subsection{Inhibition of bacterial AcpS}

Binding of more than one ligand to other proteins has been reported and utilized in the design and optimization of inhibitors. For example, two inhibitor molecules were found in the active site of an aspartic proteinase, plasmepsin II from Plasmodium falciparum (PDB entry 2bju; Prade et al., 2005), and two ligands bind the E2 transactivation domain of human papillomavirus type 11 (PDB entry 1r6n; Wang et al., 2004; Yoakim et al., 2003; White et al., 2003). In the latter case, inhibitors were shown to antagonize the interaction of $\mathrm{E} 2$ with E1 helicase. The occurrence of the two 3',5'-ADP molecules in the $\mathrm{AcpS}_{\mathrm{BA}}$ structure may be a clue to the design of inhibitors that may prevent the binding of CoA. Their affinity might be comparable to that of CoA primarily based on similar binding of $\mathrm{ADP}_{\mathrm{I}}$ and the nucleotide part of $\mathrm{CoA}$ in $\mathrm{AcpS}_{\mathrm{VC}}, \mathrm{AcpS}_{\mathrm{BS}}$ and $\mathrm{AcpS}_{\mathrm{SC}}$. Superposition of the $\mathrm{AcpS}_{\mathrm{BA}}$ structure (PDB entry 3hyk) with the $\mathrm{AcpS}_{\mathrm{VC}}$ structure (PDB entry 3qmn) has revealed further interesting details that could be useful in the design of inhibitors. For example, the $\mathrm{P}$ atom of the $5^{\prime}-\beta$-phosphate of $\mathrm{CoA} / \mathrm{K}$ (Fig. $3 c$ ) is only 2.74 and $1.33 \AA$ from the $\mathrm{P}$ atom of the $3^{\prime}-\mathrm{P}$ of $\mathrm{ADP}_{\mathrm{II}}$ (Fig. $4 c$ ) and Mg-III (Fig. $4 f)$, respectively. Moreover, the conserved $\operatorname{Arg} 28$ that is known to be crucial for ACP-AcpS binding (Parris et al., 2000) interacts with $\mathrm{ADP}_{\mathrm{II}}$ in the $\mathrm{AcpS}_{\mathrm{BA}}$ structure (Fig. 4c) and with the P-pant moiety of some CoAs in $\mathrm{AcpS}_{\mathrm{VC}}$ and other available CoA-AcpS complex structures. Thus, similar contacts between the P-pant group of CoA with $\mathrm{AcpS}_{\mathrm{VC}}$ and $\mathrm{AcpS}_{\mathrm{BS}}$ and between $\mathrm{ADP}_{\mathrm{II}}$ with $\mathrm{AcpS}_{\mathrm{BA}}$ may strengthen the binding of potential CoA inhibitors. Although the unusual presence of $\mathrm{ADP}_{\mathrm{II}}$ depends in part on lattice packing and the

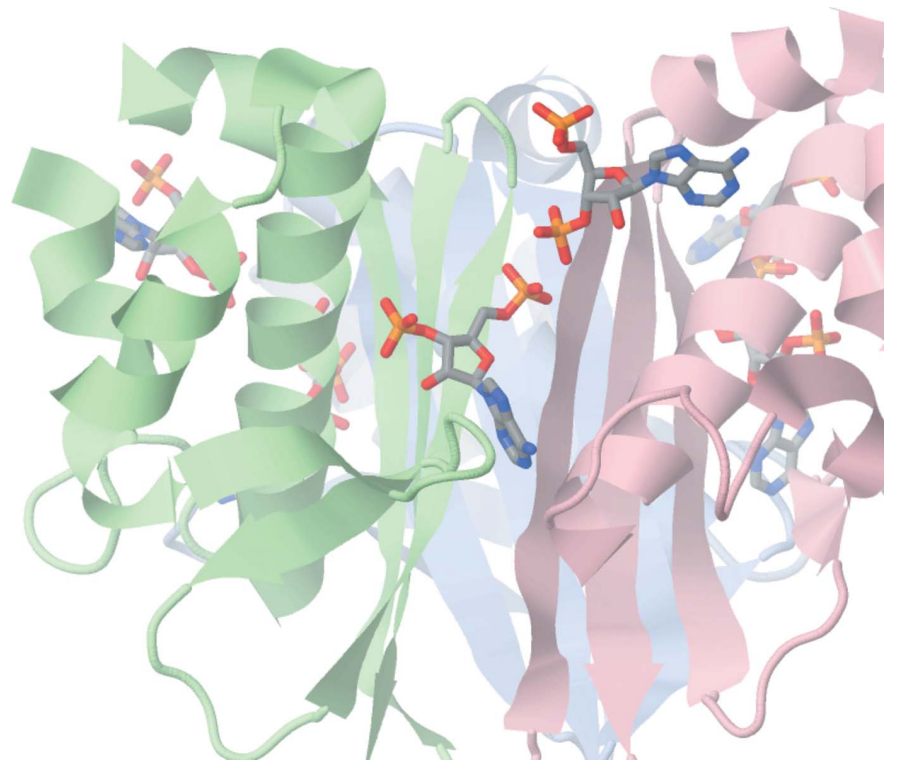

Figure 7

Strategy for inhibition of bacterial AcpS. high concentration of magnesium (Figs. $4 d, 4 e$ and $4 f$ ), it could also block and/or decrease the affinity of ACP-AcpS interaction (Fig. 6). Superposition of the $\mathrm{AcpS}_{\mathrm{BA}}$ and $\mathrm{ACP}_{\mathrm{BS}^{-}}$ $\mathrm{AcpS}_{\mathrm{BS}}$ complex (PDB entry 1f80) structures has shown that $\mathrm{ADP}_{\text {II }}$ clashes with the predicted positions of residues Gly33Glu41 in $\mathrm{ACP}_{\mathrm{BS}}$ (Fig. 6). This region contains the active Ser36. There is a resemblance between the $\mathrm{ADP}_{\mathrm{II}} \mathrm{O}^{\prime}-$ $\mathrm{AcpS}_{\mathrm{BA}}$ Arg14 interaction (Fig. 4c) and the $\mathrm{ACP}_{\mathrm{BS}}$ Asp35/ Asp38-AcpS ${ }_{B S}$ Arg14 interaction, with the latter being important for the correct orientation of Ser36 of the carrier protein in the P-pant transfer reaction (Parris et al., 2000). The rest of the $\mathrm{ADP}_{\mathrm{II}}$ atoms do not mimic any of the $\mathrm{ACP}_{\mathrm{BS}^{-}}$ $\mathrm{AcpS}_{\mathrm{BS}}$ contacts, but instead interact with Lys70 and Glu71 of the symmetry-related chain $C$ and $\operatorname{Arg} 84$ of the symmetryrelated chain $B$. Hydrophobic interactions play a predominant role in the formation of a complex between human AcpS and its cognate $\mathrm{ACP}$, whereas ionic forces stabilize complexes between the bacterial homologs (Bunkoczi et al., 2007). Therefore, a bulky hydrophilic ligand similar to the two $3^{\prime}, 5^{\prime}$-ADP molecules may specifically target bacterial AcpS (Fig. 7). Lastly, it is important to stress the specific $\mathrm{ADP}_{\mathrm{I}} 5^{\prime}-\mathrm{P}-$ $\mathrm{ADP}_{\mathrm{II}} 3^{\prime}-\mathrm{P}$ interaction through $\mathrm{Mg}$-III. The preference for the observed $\mathrm{ADP}_{\mathrm{I}} 5^{\prime}-\mathrm{P}-\mathrm{Mg}-\mathrm{III}-\mathrm{ADP}_{\mathrm{II}} 3^{\prime}-\mathrm{P}$ interaction as opposed to an $\mathrm{ADP}_{\mathrm{I}} 5^{\prime}-\mathrm{P}-\mathrm{Mg}-\mathrm{III}-\mathrm{ADP}_{\mathrm{II}} 5^{\prime}-\mathrm{P}$ interaction is most likely to reflect the energy minimum for both $3^{\prime}, 5^{\prime}$-ADPs to interact in the protein crystal lattice. Although we think that $\mathrm{ADP}_{\mathrm{II}}$ is a crystallographic artifact, the biological relevance of $\mathrm{ADP}_{\mathrm{II}}$ should be further investigated.

\section{Conclusions}

The importance of FAS II structural studies for the development of effective therapeutics continues to stimulate research to discover and characterize homologous FAS II enzymes from a variety of human pathogens. AcpS is an important enzyme in regulation of the FAS II pathway. This protein triggers FAS II by post-translationally modifying ACP. We have determined three structures of the AcpS enzymes from three different human pathogens. Consistent with previously published data, our results also imply that these enzymes do not significantly change their tertiary structures upon binding substrates. A limiting factor in the production of the desired ACP intermediates in FAS II seems to be the quaternary architecture of AcpS. The high concentration of magnesium in the crystallization condition resulted in the hydrolysis of CoA by $\mathrm{AcpS}_{\mathrm{BA}}$ even in the absence of ACP. The unusual binding of $\mathrm{ADP}_{\mathrm{II}}$ in $\mathrm{AcpS}_{\mathrm{BA}}$ suggests a strategy for the inhibition of bacterial AcpS. For example, the presence of a bulky ligand that would mimic the two bound $3^{\prime}, 5^{\prime}$-ADP molecules at the interaction interface between two adjacent monomers in the AcpS trimer may prevent the binding of $\mathrm{CoA}$ and/or the formation of a productive CoA-AcpS-ACP complex.

We acknowledge the staff of the Life Sciences Collaborative Access Team beamline 21ID-F [use of the LS-CAT Sector 21 was supported by the Michigan Economic Development 
Corporation and the Michigan Technology Tri-Corridor for the support of this research program (Grant 085P1000817)] and the Structural Biology Center beamline 19-ID at the Advanced Photon Source, Argonne National Laboratory for their help during diffraction data collection. Use of the Advanced Photon Source was supported by the US Department of Energy, Office of Science, Office of Basic Energy Sciences under Contract No. DE-AC02-06CH11357. The CSGID project has been funded in whole or in part with Federal funds from the National Institute of Allergy and Infectious Diseases, National Institutes of Health (NIH), Department of Health and Human Services under Contract No. HHSN272200700058C (to WFA).

\section{References}

Adams, P. D. et al. (2010). Acta Cryst. D66, 213-221.

Black, C. B., Huang, H.-W. \& Cowan, J. A. (1994). Coord. Chem. Rev. 135/136, 165-202.

Brinster, S., Lamberet, G., Staels, B., Trieu-Cuot, P., Gruss, A. \& Poyart, C. (2009). Nature (London), 458, 83-86.

Brody, S., Oh, C., Hoja, U. \& Schweizer, E. (1997). FEBS Lett. 408, 217-220.

Bunkoczi, G., Pasta, S., Joshi, A., Wu, X., Kavanagh, K. L., Smith, S. \& Oppermann, U. (2007). Chem. Biol. 14, 1243-1253.

Campbell, J. W. \& Cronan, J. E. Jr (2001). Annu. Rev. Microbiol. 55, 305-332.

Carreras, C. W., Gehring, A. M., Walsh, C. T. \& Khosla, C. (1997). Biochemistry, 36, 11757-11761.

Chalut, C., Botella, L., de Sousa-D'Auria, C., Houssin, C. \& Guilhot, C. (2006). Proc. Natl Acad. Sci. USA, 103, 8511-8516.

Chen, V. B., Arendall, W. B., Headd, J. J., Keedy, D. A., Immormino, R. M., Kapral, G. J., Murray, L. W., Richardson, J. S. \& Richardson, D. C. (2010). Acta Cryst. D66, 12-21.

Chirgadze, N. Y., Briggs, S. L., McAllister, K. A., Fischl, A. S. \& Zhao, G. (2000). EMBO J. 19, 5281-5287.

Chu, M., Mierzwa, R., Xu, L., Yang, S. W., He, L., Patel, M., Stafford, J., Macinga, D., Black, T., Chan, T.-M. \& Gullo, V. (2003). Bioorg. Med. Chem. Lett. 13, 3827-3829.

Chuman, L. \& Brody, S. (1989). Eur. J. Biochem. 184, 643-649.

Cowtan, K. (1994). Jnt CCP4/ESF-EACBM Newsl. Protein Crystallogr. 31, 34-38.

Cowtan, K. (2006). Acta Cryst. D62, 1002-1011.

Dall'aglio, P., Arthur, C. J., Williams, C., Vasilakis, K., Maple, H. J., Crosby, J., Crump, M. P. \& Hadfield, A. T. (2011). Biochemistry, 50, 5704-5717.

Davis, I. W., Leaver-Fay, A., Chen, V. B., Block, J. N., Kapral, G. J., Wang, X., Murray, L. W., Arendall, W. B., Snoeyink, J., Richardson, J. S. \& Richardson, D. C. (2007). Nucleic Acids Res. 35, W375W383.

DeLano, W. L. (2002). PyMOL. http://www.pymol.org.

Donato, H., Krupenko, N. I., Tsybovsky, Y. \& Krupenko, S. A. (2007). J. Biol. Chem. 282, 34159-34166.

Dym, O., Albeck, S., Peleg, Y., Schwarz, A., Shakked, Z., Burstein, Y. \& Zimhony, O. (2009). J. Mol. Biol. 393, 937-950.

Elovson, J. \& Vagelos, P. R. (1968). J. Biol. Chem. 243, 3603-3611.

Elovson, J. \& Vagelos, P. R. (1975). Arch. Biochem. Biophys. 168, 490-497.

Emsley, P. \& Cowtan, K. (2004). Acta Cryst. D60, 2126-2132.

Fischl, A. S. \& Kennedy, E. P. (1990). J. Bacteriol. 172, 5445-5449.

Flugel, R. S., Hwangbo, Y., Lambalot, R. H., Cronan, J. E. \& Walsh, C. T. (2000). J. Biol. Chem. 275, 959-968.

Gilbert, A. M., Kirisits, M., Toy, P., Nunn, D. S., Failli, A., Dushin, E. G., Novikova, E., Petersen, P. J., Joseph-McCarthy, D.,
McFadyen, I. \& Fritz, C. C. (2004). Bioorg. Med. Chem. Lett. 14, 37-41.

Glusker, J. P., Katz, A. K. \& Bock, C. W. (2001). Struct. Chem. 12, 323-341.

Gouet, P., Courcelle, E., Stuart, D. I. \& Métoz, F. (1999). Bioinformatics, 15, 305-308.

Gräslund, S. et al. (2008). Nature Methods, 5, 135-146.

Holm, L. \& Park, J. (2000). Bioinformatics, 16, 566-567.

Jackowski, S. \& Rock, C. O. (1984). J. Biol. Chem. 259, 1891-1895.

Jenni, S., Leibundgut, M., Boehringer, D., Frick, C., Mikolásek, B. \& Ban, N. (2007). Science, 316, 254-261.

Johansson, P., Mulinacci, B., Koestler, C., Vollrath, R., Oesterhelt, D. \& Grininger, M. (2009). Structure, 17, 1063-1074.

Keating, D. H., Carey, M. R. \& Cronan, J. E. (1995). J. Biol. Chem. 270, 22229-22235.

Keating, D. H., Zhang, Y. \& Cronan, J. E. (1996). J. Bacteriol. 178, 2662-2667.

Kim, Y., Dementieva, I., Zhou, M., Wu, R., Lezondra, L., Quartey, P., Joachimiak, G., Korolev, O., Li, H. \& Joachimiak, A. (2004). J. Struct. Funct. Genomics, 5, 111-118.

Lambalot, R. H., Gehring, A. M., Flugel, R. S., Zuber, P., LaCelle, M., Marahiel, M. A., Reid, R., Khosla, C. \& Walsh, C. T. (1996). Chem. Biol. 3, 923-936.

Lambalot, R. H. \& Walsh, C. T. (1995). J. Biol. Chem. 270, 2465824661.

Laskowski, R. A., MacArthur, M. W., Moss, D. S. \& Thornton, J. M. (1993). J. Appl. Cryst. 26, 283-291.

Leibundgut, M., Jenni, S., Frick, C. \& Ban, N. (2007). Science, 316, 288-290.

Leibundgut, M., Maier, T., Jenni, S. \& Ban, N. (2008). Curr. Opin. Struct. Biol. 18, 714-725.

Lomakin, I. B., Xiong, Y. \& Steitz, T. A. (2007). Cell, 129, 319-332.

Magnuson, K., Jackowski, S., Rock, C. O. \& Cronan, J. E. (1993). Microbiol. Rev. 57, 522-542.

Maier, T., Jenni, S. \& Ban, N. (2006). Science, 311, 1258-1262.

Maier, T., Leibundgut, M. \& Ban, N. (2008). Science, 321, 1315-1322.

McCoy, A. J., Grosse-Kunstleve, R. W., Adams, P. D., Winn, M. D., Storoni, L. C. \& Read, R. J. (2007). J. Appl. Cryst. 40, 658-674.

Miinalainen, I. J., Chen, Z.-J., Torkko, J. M., Pirilä, P. L., Sormunen, R. T., Bergmann, U., Qin, Y.-M. \& Hiltunen, J. K. (2003). J. Biol. Chem. 278, 20154-20161.

Minor, W., Cymborowski, M., Otwinowski, Z. \& Chruszcz, M. (2006). Acta Cryst. D62, 859-866.

Mofid, M. R., Finking, R., Essen, L. O. \& Marahiel, M. A. (2004). Biochemistry, 43, 4128-4136.

Mootz, H. D., Finking, R. \& Marahiel, M. A. (2001). J. Biol. Chem. 276, 37289-37298.

Morris, R. J., Perrakis, A. \& Lamzin, V. S. (2003). Methods Enzymol. 374, 229-244.

Murshudov, G. N., Skubák, P., Lebedev, A. A., Pannu, N. S., Steiner, R. A., Nicholls, R. A., Winn, M. D., Long, F. \& Vagin, A. A. (2011). Acta Cryst. D67, 355-367.

Nakanishi, M., Yatome, C., Ishida, N. \& Kitade, Y. (2001). J. Biol. Chem. 276, 46394-46399.

Nishida, H. \& Nishiyama, M. (2000). J. Mol. Evol. 51, 299-302.

Otwinowski, Z. (1991). Proceedings of the CCP4 Study Weekend. Isomorphous Replacement and Anomalous Scattering, edited by W. Wolf, P. R. Evans \& A. G. W. Leslie, pp. 80-86. Warrington: Daresbury Laboratory.

Otwinowski, Z. \& Minor, W. (1997). Methods Enzymol. 276, 307-326.

Parris, K. D., Lin, L., Tam, A., Mathew, R., Hixon, J., Stahl, M., Fritz, C. C., Seehra, J. \& Somers, W. S. (2000). Structure, 8, 883-895.

Powell, G. L., Elovson, J. \& Vagelos, P. R. (1969). J. Biol. Chem. 244, 5616-5624.

Prade, L., Jones, A. F., Boss, C., Richard-Bildstein, S., Meyer, S., Binkert, C. \& Bur, D. (2005). J. Biol. Chem. 280, 23837-23843.

Praphanphoj, V., Sacksteder, K. A., Gould, S. J., Thomas, G. H. \& Geraghty, M. T. (2001). Mol. Genet. Metab. 72, 336-342. 
Quadri, L. E., Weinreb, P. H., Lei, M., Nakano, M. M., Zuber, P. \& Walsh, C. T. (1998). Biochemistry, 37, 1585-1595.

Reuter, K., Mofid, M. R., Marahiel, M. A. \& Ficner, R. (1999). EMBO J. 18, 6823-6831.

Schneider, R., Brors, B., Burger, F., Camrath, S. \& Weiss, H. (1997). Curr. Genet. 32, 384-388.

Schneider, R., Brors, B., Massow, M. \& Weiss, H. (1997). FEBS Lett. 407, 249-252.

Schweizer, E. \& Hofmann, J. (2004). Microbiol. Biol. Rev. 68, 501-517.

Sheldrick, G. M. (2008). Acta Cryst. A64, 112-122.

Smith, S., Witkowski, A. \& Joshi, A. K. (2003). Prog. Lipid Res. 42, 289-317.

Vagelos, P. R. (1973). The Enzymes, 3rd ed., edited by P. D. Boyer, pp. 155-199. New York: Academic Press.

Vagelos, P. R. \& Larrabes, A. R. (1967). J. Biol. Chem. 242, 17761781.

Vedadi, M. et al. (2007). Mol. Biochem. Parasitol. 151, 100-110.

Wakil, S. J., Stoops, J. K. \& Joshi, V. C. (1983). Annu. Rev. Biochem. 52, 537-579.

Wallace, A. C., Laskowski, R. A. \& Thornton, J. M. (1995). Protein Eng. 8, 127-134.
Wang, Y., Coulombe, R., Cameron, D. R., Thauvette, L., Massariol, M. J., Amon, L. M., Fink, D., Titolo, S., Welchner, E., Yoakim, C., Archambault, J. \& White, P. W. (2004). J. Biol. Chem. 279, 69766985.

Wang, J. et al. (2006). Nature (London), 441, 358-361.

Wang, J. et al. (2007). Proc. Natl Acad. Sci. USA, 104, 7612-7616.

White, P. W., Titolo, S., Brault, K., Thauvette, L., Pelletier, A., Welchner, E., Bourgon, L., Doyon, L., Ogilvie, W. W., Yoakim, C., Cordingley, M. G. \& Archambault, J. (2003). J. Biol. Chem. 278, 26765-26772.

White, S. W., Zheng, J., Zhang, Y.-M. \& Rock, C. O. (2005). Annu. Rev. Biochem. 74, 791-831.

Winn, M. D. et al. (2011). Acta Cryst. D67, 235-242.

Yoakim, C., Ogilvie, W. W., Goudreau, N., Naud, J., Haché, B., O'Meara, J. A., Cordingley, M. G., Archambault, J. \& White, P. W. (2003). Bioorg. Med. Chem. Lett. 13, 2539-2541.

Zhang, Y.-M., Frank, M. W., Virga, K. G., Lee, R. E., Rock, C. O. \& Jackowski, S. (2004). J. Biol. Chem. 279, 50969-50975.

Zhang, Y.-M. \& Rock, C. O. (2008). Nature Rev. Microbiol. 6, 222-233.

Zhang, Y.-M., White, S. W. \& Rock, C. O. (2006). J. Biol. Chem. 281, 17541-17544. 